\title{
Infection Source of Herpesvirus Disease in Coho Salmon Culture and its Control
}

\author{
Akira Kumagai*1, Kiyotaka Takahashi*2 and Hideo Fukuda*3 \\ *1 Miyagi Prefectural Freshwater Fisheries Experimental Station, Taiwa, Miyagi 981-36, Japan \\ ${ }^{*} 2$ Miyagi Prefecture Fisheries Research and Development Center, Watanoha, Ishinomaki, 986-21, Japan \\ ${ }^{*}$ Laboratory of Aquatic Pathology, Department of Aquatic Biosciences, Tokyo University of \\ Fisheries, Konan 4, Minato, Tokyo 108, Japan
}

(Received November 22, 1996)

\begin{abstract}
Epizootiological surveys on salmonid herpesvirus-2 (SaHV-2) infection in coho salmon (Oncorhynchus kisutch) culture were undertaken at freshwater hatcheries and seawater farms in order to clarify the infection source. At seawater farms, the outbreaks were observed only in the fish populations derived from particular hatcheries, and in some cases, the disease was observed during the seawater acclimatization period. Outbreaks during mariculture period tended to occur repeatedly year after year when the seedlings were introduced from hatcheries where coho salmon was reared together with other salmonids. On the other hand, in fish derived from hatcheries where only coho salmon was reared, the outbreak occurred only when the hatchery replenished the juveniles from virally contaminated hatcheries. In the surveillance of virus carrier fish, SaHV-2 highly virulent to coho salmon was isolated from apparently normal rainbow trout collected at a hatchery, where coho salmon seedlings supplied every year had been found to be contaminated. These results suggest that the SaHV-2 infection to coho salmon occurred at freshwater hatcheries and that the transportation of infected juveniles spread the virus among the hatcheries. It was also suggested that the infection source might be asymptomatically infected other salmonid species which were reared together with coho salmon.
\end{abstract}

Key words: herpesvirus disease, coho salmon, infection source, salmonid herpesvirus 2, SaHV-2, rainbow trout

In Japan, the mariculture of coho salmon started in 1975 and has been advancing rapidly. Annual production of coho salmon rose up to 27,000 tons in 1991 . Almost all the seed stocks for coho salmon hatcheries in Tohoku district are eyed eggs imported from USA, and adult stocks are rarely reared in these hatcheries. The hatcheries receive the eggs from December to January and rear them for 10 to 11 months until juveniles come to smolts. Then the smolts, weighing $100-200 \mathrm{~g}$, are supplied to mariculture farms as seedlings. The herpesvirus disease mainly occurs during the period of mariculture, especially from late winter to spring, and the damages caused by the disease often rise up to 10 $30 \%$ of rearing fish in mariculture farms (Kumagai et al., 1994a).

There have been many reports on salmonid herpesvirus 2 from Japanese salmonid fishes. The virus is widely distributed in the northern part of Japan and causes mass mortality and/or basal cell tumor (Sano, 1976; Kimura et al., 1981; Yoshimizu et al., 1989; Kumagai et al., 1994a). SaHV-2, the abbreviation of the virus, was proposed by ICTV's 6th report on the virus taxonomy (Murphy et al., 1995). The virulence of SaHV-2 isolated from freshwater salmonids was reported low to coho salmon compared with kokanee, chum and masu salmon (Kimura et al., 1981). However, Kumagai et al. (1995) reported that the isolate $\mathrm{CSH}$, the causative virus of coho salmon herpesvirus disease, had high virulence to coho salmon and low virulence to masu salmon.

Although it has been suggested that the infection of the virus might occur during the freshwater rearing period (Kimura and Yoshimizu, 1991; Kumagai et al., 1994a), the epizootiology, especially the infection source has not been determined. In the present study, we describe the results of epizootiological surveys for SaHV-2 infection in coho salmon culture. 


\section{Materials and Methods}

\section{Relationship between the outbreak of herpesvirus disease and the origin of the seedlings}

Epizootiological study of SaHV-2 was undertaken at coho salmon mariculture farms located in northern part of Miyagi Prefecture in mariculture seasons of 1990 and 1991. Twenty mariculture farms (No. 1-20 in Fig. 1) were selected for the investigation. Ten(No. 1-10) of them had the disease, while other 10 (No. 11-20) did not. Freshwater hatcheries from which these farms introduced seedlings were traced. The occurrence of the disease was examined by the virus detection method reported (Kumagai et al., 1994b). At the freshwater hatcheries which was considered to be contaminated by the virus, the history of juveniles introduced from other hatcheries during the past several years was also traced.

\section{Survey of virus carrier fish in freshwater hatchery}

Since the hatchery A had been considered to be contaminated by the virus, virus examination on adult rainbow trout reared in the hatchery was performed in December of 1992 . Ovarian fluids from 65 apparently normal rainbow trout were collected according to the method of Yoshimizu et al. (1985). One $\mathrm{m} l$ of ovarian fluid was taken from the urogenital opening using sterilized micropipette tip. The fluids from each five fish were pooled and separated into two aliquots. One was treated with antibiotics (Penicillin 1,000IU/ml, Streptomycin $1,000 \mu \mathrm{g} / \mathrm{m} l$ and Fungizone $400 \mathrm{IU} / \mathrm{ml}$ ) for $2 \mathrm{~h}$ at $15^{\circ} \mathrm{C}$. Since the spawning rainbow trout are often asymptomatic carriers of IHNV and/or IPNV, another aliquot was additionally treated with anti-IHNV $\left(10 \mathrm{ND}_{50}\right)$ and anti-IPNV(anti-Buhl, Sp and Ab: ca $120 \mathrm{ND}_{50}$ each) sera for $2 \mathrm{~h}$ at $15^{\circ} \mathrm{C}$. The treated solutions were inoculated onto a monolayer of the chinook salmon embryo cell line (CHSE-214), and incubated at $15^{\circ} \mathrm{C}$ for 14 days. The isolated viruses were identified with neutralization tests using anti-SaHV2 (NeVTA isolate) and anti-IHNV serum.

\section{Pathogenicity of the virus isolated from rainbow trout}

The pathogenicity of the rainbow trout isolate (RTH9201), which was isolated in surveillance mentioned above, to three salmonid species was compared with that of coho salmon isolate, CSH9003 (Kumagai et al., 1994a). Twenty healthy coho salmon juvenile (mean body weight $12 \mathrm{~g}$ ), masu salmon $(12 \mathrm{~g})$ and rainbow trout $(8 \mathrm{~g})$, were injected intraperitoneally with $10^{4.1} \mathrm{TCID}_{50} /$ fish for each isolate. Control groups were treated as the same with injection of Minimum Essential Medium supplemented with 2\% of fetal calf serum. After inoculation, the fish were kept at $9^{\circ} \mathrm{C}$ for 30 days in running freshwater and dead fish were sampled for virus examination.

\section{Results}

Relationship between the outbreak of herpesvirus disease and the origin of the seedlings

In most cases, seawater farms used seedlings produced in several hatcheries (code No. A to P in Fig. 1). All 10 hatcheries where outbreaks of SaHV-2 infection occurred in 1990, introduced seedlings either from hatcheries A or from B. While in the other farms where no outbreak was observed, no seedlings were introduced from either A or B hatcheries (Fig. 1). Small number of seedlings from A and B died with clinical signs of SaHV-2 infection during seawater acclimatization period and SaHV-2 was isolated from the dead fish.

In 1991, farms introduced seedlings from hatcheries A, B, C, D and/or E, suffered damage from the disease. In the acclimatization period, fish from those hatcheries also died with the disease. In other 10 farms without those seedlings the disease was not noticed (Fig. 1).

Although the farms put their pens next to next, pen to pen transmission of the disease was not noticed in both years.

History of juvenile transportation and spread of SaHV-2

Juvenile transportation and spread of SaHV-2 cotamination were shown in Fig. 2. Hatchery A replenished juveniles from hatchery $\mathrm{Q}$ in 1984 , and supplied seedlings to several seawater farms. Afterward, basal cell tumor development on the fish derived from $\mathrm{Q}$ and $\mathrm{A}$ was noticed during mariculture period of 1985 and SaHV-2 (CSTV isolate) was isolated from those tumor tissues (Sano, 1988)*1. In 1987, juveniles were transported from hatchery $Q$ to $R, S$ and $T$ hatcheries and the tumor was developed on those fish at seawater farms. The juveniles cultured in hatchery C were transported to D and E in 1990 and mortalities caused by the virus occurred in the maricultured fish derived from C, D and E in 1991.

In some investigated hatcheries, other salmonid fishes,

\footnotetext{
*1 Sano, T. (1988): Characterization, pathogenicity and oncogenicity of herpesviruses in fish. Abstract from the American Fisheries Society, Fish Health Section International Fish Health Conference, Vancouver, British Colombia, Canada. July 19-21. pp. 157.
} 
1990

\begin{tabular}{|c|c|c|}
\hline $\begin{array}{l}\text { Sea water } \\
\text { farm }\end{array}$ & $\begin{array}{l}\text { Outbreak of } \\
\text { the disease }\end{array}$ & $\begin{array}{c}\text { Origin of seedlings (Code of hatcheries) } \\
\text { A B C DE F H I J K L M }\end{array}$ \\
\hline $\begin{array}{r}1 \\
2 \\
3 \\
4 \\
5 \\
6 \\
7 \\
8 \\
9 \\
10 \\
11 \\
12 \\
13 \\
14 \\
15 \\
16 \\
17 \\
18 \\
19 \\
20\end{array}$ & $\begin{array}{l}\text { Yes } \\
\text { Yes } \\
\text { Yes } \\
\text { Yes } \\
\text { Yes } \\
\text { Yes } \\
\text { Yes } \\
\text { Yes } \\
\text { Yes } \\
\text { Yes } \\
\text { No } \\
\text { No } \\
\text { No } \\
\text { No } \\
\text { No } \\
\text { No } \\
\text { No } \\
\text { No } \\
\text { No } \\
\text { No }\end{array}$ & $\begin{array}{lll}0 & 0 & 0 \\
0 & 0 & 0 \\
0 & 0 & 0 \\
0 & 0\end{array}$ \\
\hline
\end{tabular}

1991

\begin{tabular}{|c|c|c|}
\hline $\begin{array}{l}\text { Sea water } \\
\text { farm }\end{array}$ & $\begin{array}{l}\text { Outbreak of } \\
\text { the disease }\end{array}$ & $\begin{array}{l}\text { Origin of seedlings (Code of hatcheries) } \\
\text { A B C D F G I J } N O P\end{array}$ \\
\hline $\begin{array}{r}1 \\
2 \\
3 \\
4 \\
5 \\
6 \\
7 \\
8 \\
9 \\
10 \\
11 \\
12 \\
13 \\
14 \\
15 \\
16 \\
17 \\
18 \\
19 \\
20\end{array}$ & $\begin{array}{l}\text { Yes } \\
\text { Yes } \\
\text { Yes } \\
\text { Yes } \\
\text { Yes } \\
\text { Yes } \\
\text { Yes } \\
\text { Yes } \\
\text { Yes } \\
\text { Yes } \\
\text { No } \\
\text { No } \\
\text { No } \\
\text { No } \\
\text { No } \\
\text { No } \\
\text { No } \\
\text { No } \\
\text { No } \\
\text { No }\end{array}$ & $\begin{array}{lll}8 & 0 \\
8 & & \\
0 & & 0 \\
0 & 0 & \\
0 & 0 & \\
0 & 0 & 0 \\
0 & 0 & 0 \\
0 & 0 & 0\end{array}$ \\
\hline
\end{tabular}

Fig. 1. Relationship between the outbreak of the disease in maricultured coho salmon and the origin of the seedlings.

The disease occurred only in the farms which contain the fish derived from A or B hatchery in 1990 and from A, B, C, D or $\mathrm{E}$ in 1991. 


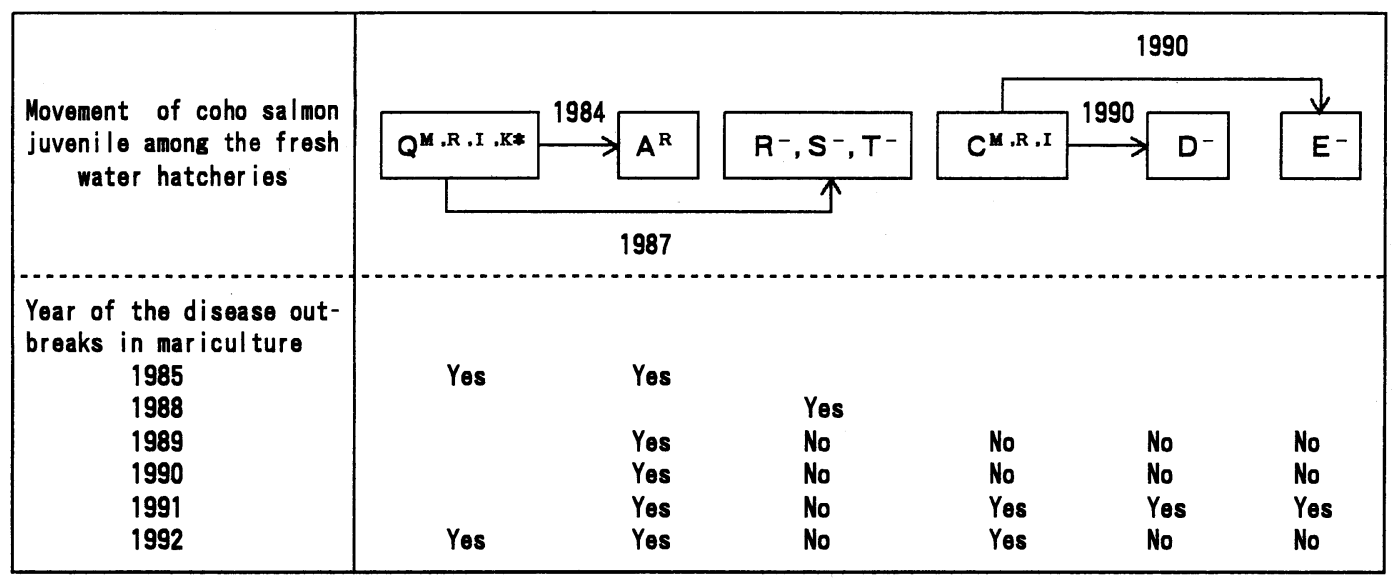

Fig. 2. Spread of SaHV-2 contamination among freshwater hatcheries due to the transportation of virally infected juvenile. The disease occurred after introduction of juveniles from virally contaminated hatcheries and continuous outbreaks were recorded in the farms where other salmonids were reared together with coho salmon.

* The large letters indicate the code of hatchery and the samll letters indicate the fish species reared together with coho salmon in each hatchery. M: Masu salmon (Oncorhynchus masou), R: Rainbow trout (O. mykiss), I: Japanese char (Salvelinus pluvius), K: Kokanee salmon (O. nerka) and -: no other salmonid.

Table 1. Virus examination on ovarian fluids of mature rainbow trout reared together with coho salmon juvenile in hatchery $A^{* 1}$

\begin{tabular}{lcc}
\hline \hline \multirow{2}{*}{ No. of Samples*2 } & \multicolumn{2}{c}{ CPE positive samples } \\
\cline { 2 - 3 } & $\begin{array}{l}\text { Not treated with } \\
\text { anti sera }\end{array}$ & $\begin{array}{l}\text { Treated with Anti-IHNV } \\
\text { and Anti-IPNV sera }\end{array}$ \\
\hline 13 & $13(\mathrm{IHNV})$ & $4(\mathrm{SaHV}-2)$ \\
\hline$* 1$ & The samples treated with antibiotics (Penicillin $1,000 \mathrm{IU} / \mathrm{m} l$, Streptomycin \\
$1,000 \mu \mathrm{g} / \mathrm{m} l$ and Fungizone $400 \mathrm{IU} / \mathrm{m} l)$ for $2 \mathrm{~h}$ at $15^{\circ} \mathrm{C}$ before inoculation onto \\
CHSE-214 cells.
\end{tabular}

masu salmon, rainbow trout, Japanese char (Salvelinus pluvius) and/or kokanee salmon (O. nerka) were reared together with coho salmon. When seedlings were supplied from these multi-species cultivating hatcheries and when hatcheries were contaminated by the virus, outbreaks tended to occur repeatedly, as it is seen in the population from hatchery $A$. While, in the case seedlings were supplied from the hatcheries which reared exclusively coho salmon, such as D, E, R, S and T, outbreaks occurred only in the occasion of juvenile replenishments from contaminated hatcheries (Fig. 2).

\section{Survey of virus carrier fish in freshwater hatchery}

The results of virus examinations on rainbow trout reared in hatchery A are shown in Table 1. SaHV-2 was isolated from 4 out of 13 pooled ovarian fluids after the treatment with anti-IHNV and anti-IPNV sera. Those isolates were neutralized by the anti-SaHV-2 serum. When the serum treatment was omitted, IHNV was isolated from all the samples.

\section{Pathogenicity of the virus isolated from rainbow trout}

The results of infection trials were shown in Table 2 . The cumulative mortality of coho salmon injected with RTH9201 and CSH9003 rose up to $95 \%$ and $100 \%$, respectively, while no mortality was observed in masu salmon and rainbow trout. Virus was reisolated from all dead fish examined $(n=10)$. 
Table 2. Pathogenicity of SaHV-2 isolates RTH9201 from rainbow trout and CSH9003 from maricultured coho salmon to three salmonid fishes*1

\begin{tabular}{clccc}
\hline \hline $\begin{array}{c}\text { Fish } \\
\text { (Body weight) }\end{array}$ & Isolate & $\begin{array}{l}\text { No. of } \\
\text { fish }\end{array}$ & $\begin{array}{l}\text { No. of } \\
\text { death }\end{array}$ & $\begin{array}{c}\text { Cumulative } \\
\text { mortality(\%) }\end{array}$ \\
\hline $\begin{array}{clc}\text { Coho salmon } \\
(12 \mathrm{~g})\end{array}$ & RTH9210 & 20 & 19 & 95 \\
& CSH9003 & 20 & 20 & 100 \\
Control*2 & 20 & 0 & 0 \\
\hline Masu salmon & RTH9201 & 20 & 0 & 0 \\
$(12 \mathrm{~g})$ & CSH9003 & 20 & 0 & 0 \\
& Control & 20 & 0 & 0 \\
\hline Rainbow trout & RTH9201 & 20 & 0 & 0 \\
(8g) & CSH9003 & 20 & 0 & 0 \\
& Control & 20 & 0 & 0 \\
\hline
\end{tabular}

*1 The fish intraperitoneally injected with $10^{4.1} \mathrm{TCID}_{50} /$ fish of each isolates, were reared at $9^{\circ} \mathrm{C}$ for 30 days.

*2 Control groups were treated the same way as infection groups but without the virus.

\section{Discussion}

This study was undertaken to search infection source and control measurement for coho salmon herpesvirus disease.

In fact, huge number of coho salmon eggs have been imported from USA every year for seed stocks of aquaculture, but the source of the virus infection would not be those eggs because the virus has not been recorded in USA (Wolf, 1988). Thus the infection should have occurred after arriving in Japan.

In 1990 and 1991, the relationship between the disease outbreaks and the origin of the seedling was surveyed. In seawater farms, the outbreaks were observed only in the fish populations derived from particular hatcheries, such as A and B in 1990 and A, B, C, D and E in 1991. In contrast, the disease did not occur in the farm without those seedlings. Additionally, those freshwater hatcheries had histories of juvenile replenishment from other hatcheries which had been supplying contaminated seedlings, such as C to D and E in 1990. So, the virus infection might have occurred in those particular freshwater hatcheries, such as A, C or Q, and spread to the area of virus contamination by the hatchery-tohatchery transportation of the infected juveniles. This idea is supported by the facts that SaHV-2 was isolated from freshwater-reared coho salmon juveniles (Horiuchi et al., 1989) and the virus easily infects coho salmon in freshwater.

In seawater farms, pen to pen transmission of the virus seems to be negligible, because outbreaks were limited in the pens rearing the fish derived from contaminated hatcheries, and because the virus is unstable in seawater (Horiuchi et al., 1989).

When fish derived from hatcheries produce exclusively coho salmon seedlings, such as D, E, R, S and $T$, outbreaks occurred only in the occasion that the hatchery has replenished juveniles from viruscontaminated hatcheries, and the outbreak has not occurred in the next year. In contrast, it occurred repeatedly in the population derived from multi-species cultivating hatcheries, such as A, C and Q. Since the brood stocks are rarely reared in Tohoku distirct, the vertical transmission from adult coho salmon would be negligible. Additionally, the shipping of seedlings to mariculture farms generally is finished before the start of rearing eggs. Therefore, there is a certain period when there is no fish left in hatcheries where coho salmon were exclusively reared. Disinfection of facilities is commonly done in this period. These facts suggest that the infection cycles may be formed in other salmonid fish in the freshwater hatcheries. This idea is supported by the facts that SaHV-2 was isolated from ovarian fluids of apparently normal rainbow trout which was reared together with coho salmon at hatchery $\mathrm{A}$, and that the isolated virus was highly virulent to coho salmon.

Conclusively, it is suggested that the infection cycles were established in other salmonids reared in the hatcheries, and the virus infection to coho salmon occurred in freshwater rearing period, and transportation of virus-infected juveniles spread the virus. Thus, coho salmon juveniles may have been infected with the virus shed from those virus carrier salmonids.

Based on these hypotheses, the authors made 
Table 3. Annual changes of the disease incidence in maricultured coho salmon in Miyagi Prefecture*1 $^{* 1}$

\begin{tabular}{|c|c|c|c|c|c|c|}
\hline & \multicolumn{6}{|c|}{ Year } \\
\hline & 1989 & 1990 & 1991 & 1992 & 1993 & 1994 \\
\hline $\begin{array}{l}\text { No. of farms examined } \\
\text { (Total No. of farms in } \\
\text { Miyagi Prefecture) }\end{array}$ & $\begin{array}{r}229 \\
(329)\end{array}$ & $\begin{array}{r}273 \\
(342)\end{array}$ & $\begin{array}{r}273 \\
(335)\end{array}$ & $\begin{array}{r}204 \\
(295)\end{array}$ & $\begin{array}{r}218 \\
(289)\end{array}$ & $\begin{array}{r}187 \\
(274)\end{array}$ \\
\hline $\begin{array}{l}\text { No. of farms in which } \\
\text { the disease occurred }\end{array}$ & 22 & 25 & 14 & 1 & 2 & 1 \\
\hline $\begin{array}{l}\text { Loss of fish caused by } \\
\text { the disease (tons) }\end{array}$ & 46.0 & 62.7 & 70.7 & 8.0 & 11.0 & 1.5 \\
\hline
\end{tabular}

*1 The data were taken from questionnaire on fish diseases recovered from each mariculture farm. The investigation was conducted by the Government of Miyagi Prefecture.

following recommendations to aquaculturists for control of the disease in 1991.

(1) Stop the culture of other salmonid species in hatcheries.

(2) Disinfection of facilities should be carried out at the end of seedling production.

(3) Careless introduction or replenishments of juveniles from virally contaminated hatcheries should be avoided.

(4) Careful observation of the fish and virus examination are needed in the seawater acclimatization period, and seedlings should be discarded when the disease was noticed during this period.

After these recommendations were made, many farmers followed them and then the prevalence of the disease was decreased dramatically in Miyagi Prefecture (Table 3).

\section{Acknowledgements}

We appreciate the cooperation of colleagues of Miyagi Prefectural Freshwater Fisheries Experimental Station and Kesennuma Miyagi Prefectural Fisheries Experimental Station. This study was supported in part by a grant from Miyagi Prefecture (Survey for controlling method of maricultured coho salmon viral disease).

\section{References}

Horiuchi, M., M. Miyazawa, M. Nakata, K. Iida and S. Nishimura (1989): A case of herpesvirus isolation of freshwater-reared coho salmon Oncorhynchus kisutch in Japan. Suisanzoushoku, 36, 297-305.
Kimura, T. and M. Yoshimizu (1991): Herpesvirus of salmonid fish in Japan. Proceedings of second international symposium on viruses of lower vertebrates, Fryer J. L. Ed. Oregon State University, Printing Department, Oregon, U.S.A., 183-189.

Kimura, T., M. Yoshimizu, M. Tanaka and H. Sannohe (1981): Studies on a new virus (OMV) from Oncorhynchus masou. I. Characteristics and pathogenicity. Fish Pathol., 15, 143147.

Kimura, T., M. Yoshimizu and M. Tanaka (1983): Susceptibility of different fry stage representative salmonid species to Oncorhynchus masou virus (OMV). Fish Pathol., 17, 251258.

Kumagai, A., K. Takahashi and H. Fukuda (1994a): Epizootics caused by salmonid herpesvirus type 2 infection in maricultured coho salmon. Fish Pathol., 29, 127-134.

Kumagai, A., H. Fukuda and K. Takahashi (1994b): Optimum method for isolation of salmonid herpesvirus type 2 from maricultured coho salmon. Fish Pathol., 29, 205-209.

Kumagai, A., K. Takahashi and H. Fukuda (1995): Pathogenicity of salmonid herpesvirus 2 from maricultured coho salmon to coho salmon and other salmonid fish. Fish Pathol., 30, 215-220.

Murphy, F., C. Fauquet, D. Bishop, S. Ghabrial, A. Jarvis, G. Martelli, M. Mayo and M. Summers (1995): Virus taxonomy, 6th report of the International Committee on Taxonomy of Viruses. Arch. Virol. Supplementum 10.

Sano, T. (1976): Viral diseases of culture fishes in Japan. Fish Pathol., 10, 221-226.

Wolf, K. (1988): Fish Viruses and fish Viral Diseases. The Univ. of Cornell Press, New York, pp. 167.

Yoshimizu, M., T. Kimura and J. R. Winton (1985): An improved technique for collecting reproductive fluid samples from salmonid fishes. Prog. Fish-Cult., 47, 199-200.

Yoshimizu, M., T. Nomura, T. Awakura, Y. Ezura and T. Kimura (1989): Prevalence of pathogenic fish viruses in anadromous masu salmon (Oncorhynchus masou) in the northern part of japan, 1976-1987. Physiol. Ecol. Japan, Spec. Vol. 1, 559-576. 